Annette Siemes

ORCID: 0000-0001-6129-0900

Uniwersytet Wrocławski

https://doi.org/10.19195/1733-5779.38.7

\title{
Transformation design a informacja naukowa. Zaistnienie nowego zjawiska w komunikacji oraz proces systematyzacji związanych z nim informacji - eksploracja teoretyczna i empiryczna
}

Slowa kluczowe: transformation design / projektowanie transformacji, komunikacja, normalność, eksperyment, warsztaty

Keywords: transformation design, communication, normality, experiment, workshop

Abstrakt: Artykuł poświęcony jest szerokiemu zagadnieniu transformation design, będącemu interdyscyplinarnym obszarem analizy i teoretycznego opisu oraz projektowania i podejmowania działań na rzecz ekologicznie, a jednocześnie prospołecznie zorientowanych zmian systemowych. Głównym pytaniem jest: czy i jak tak złożona tematyka może stać się częścią interdyskursu, wychodząc poza ramy dyskursów specjalistycznych. Ta kwestia jest analizowana na tle zarówno teoretycznym, opartym na stratyfikacji komunikacji i analizie normalności w komunikacjach, jak i praktyczno-doświadczalnym, za pomocą eksperymentalnego scenariusza warsztatów o tematach i aktywnościach w zakresie projektowania transformacji. Obie perspektywy razem umożliwiają określenie zasadniczych problemów i wyzwań wyjściowych oraz dostarczają wskazówek odnośnie do możliwości i ograniczeń form warsztatowych. W rezultacie zostaje uzyskana możliwość sformułowania strategii i stworzenia podstawy do dalszego opracowania narzędzi praktycznych.

Transformation design and scientific information.

A new phenomenon coming into being in communication and the process of systematising related information - a theoretical and empirical exploration

Abstract: The article deals with the broad issue of transformation design as an interdisciplinary field of analysis and theoretical description, as well as designing and taking action concerning ecological and, at the same time, pro-socially orientated system change. The main question is, if and how such a complex subject matter can become a part of the interdiscourse and exceed the framework of specialist discourses. This question is analysed as well on a theoretic background, based on the analysis of normality in communications, as on a practical-empirical foundation, by 
means of an experimental workshop scenario about themes and activities in the field of transformation design. Both perspectives together allow to identify fundamental problems and challenges as well as to deliver advice regarding the possibilities and limitations for the (tested) form of workshops. As a result we are enabled to frame the strategic basis for the further planning of practical instruments.

W ostatnich kilku latach pojawił się nowy obszar zainteresowań badawczych w wielu dyscyplinach z zakresu nauk humanistycznych i społecznych, określany jako transformation design ${ }^{1}$. Szeroko rzecz ujmując: transformation design, czy inaczej projektowanie transformacji, zajmuje się zarówno analitycznie, jak i od strony projektowej, to znaczy teoretycznie, praktycznie oraz strategicznie, aktualnymi wątkami i nurtami dyskursu dążącymi do zmian systemowych, które są zorientowane ekologicznie, a jednocześnie prospołecznie — zmian w obszarze tego, co w omawianym kontekście określane jest jako systemy społeczno-ekologiczne (social-ecological systems) $)^{2}$. Za pomocą tego ostatniego pojęcia z kolei podkreślone zostają: nierozerwalne powiązanie obu sfer oraz kompleksowość problemów w ramach globalnego systemu, które w ujęciu transformation design stanowią niezbędny punkt wyjścia wszelkich działań. Jednak stosowany zazwyczaj bipolarny

${ }^{1}$ Szczegółowy opis zagadnienia w kontekście badań komunikacji i normalności — zob. A. Siemes, Transformation design w kontekście projektowania komunikacji i badań normalności, Kraków 2020. Interesujący nas tu obszar został tam ukazany zarówno z perspektywy projektowej (zob. Burns C. et al., Transformation Design. RED Paper 02, London 2006, http://www.designcouncil. org.uk/resources/report/red-paper-02-transformation-design (dostęp: 2.03.2021), jak i jako szersze pole rozważań teoretycznych oraz obserwacji empirycznych — zob. na przykład H. Welzer, Samodzielne myślenie, przeł. V. Grotowicz, Słupsk 2016; B. Sommer, H. Welzer, Transformationsdesign. Wege in eine zukunftsfähige Moderne, München 2017.

Obecność i istotność transformation design jako dziedziny badań i nauki wyraża się także w rosnącej liczbie kierunków studiów poświęconych zagadnieniu (z naciskiem na różne jego aspekty); zob. na przykład https://www.gsa.ac.uk/study/graduate-degrees/design-innovation-transformation-design/; https://www.wdka.nl/programmes/lifestyle-transformation-design; https:/www. khm.de/exMedia_transformation_design/; https://hbk-bs.de/studiengaenge/transformation-design/, https://www.hs-augsburg.de/Gestaltung/Transformation-Design.html; https://design.cmu.edu/content/phd, https://www.uni-flensburg.de/portal-studium-und-lehre/studiengaenge/master/transformationsstudien/ (dostęp: 2.03.2021).

2 Dla bliższego określenia pojęcia systemów społeczno-ekologicznych orazjego roli w kontekście badań związanych z tematami, które jednocześnie zaliczyć można do obszaru transformation design, zob. Ö. Bodin, M. Tengö, Disentangling intangible social-ecological systems, „Global Environmental Change” 22, 2012, $\mathrm{nr}$ 2: „The overarching insight that societies and nature are interacting to the extent of being interdependent forms the core of all research at Stockholm Resilience Centre". Zob. też Stockholm Resilience Centre, Cracking the social-ecological code. New model disentangles interdependencies between social and ecological systems, Stockholm 2021, https:// www.stockholmresilience.org/research/research-news/2012-03-26-cracking-the-social-ecologicalcode.html (dostęp: 12.02.2021); oraz Stockholm Resilience Centre, Interacting complexities, Stockholm 2021, https://www.stockholmresilience.org/research/research-themes/interacting-complexities.html (dostęp: 12.02.2021). 
podział tych dwóch obszarów (społeczeństwa i ekologii) stanowi wyzwanie dla osób podejmujących ten temat w komunikacjach.

Równie trudnym problemem w kontekście transformation design są różnorodność odnoszących się do tego obszaru tematów szczegółowych i różny poziom ich ogólności czy konkretności. Zmiany klimatyczne i globalne ocieplenie oraz wynikające z nich wyzwania i potencjał konfliktowy na poziomie komunikacji i społeczeństwa oraz w dziedzinie ekonomii są w tej samej mierze tematami z zakresu transformation design, jak konkretna inicjatywa sąsiedzka dotycząca na przykład pielęgnacji zieleni w dzielnicy, dająca się z nieco szerszej perspektywy przypisać z kolei do aktywności z zakresu urban gardening oraz, w jeszcze szerszym ujęciu, powstająca na tle procesów urbanizacji. Do obszaru projektowania transformacji zaliczyć można zarówno tak ogólne hasła, jak zrównoważoność ${ }^{3}$ i 17 celów zrównoważonego rozwoju ${ }^{4}$ sformułowanych przez Narody Zjednoczone (w tym na przykład punkt drugi dotyczący pokonania głodu na świecie), jak i wszelkie aktywności w zakresie ratowania produktów żywnościowych przed ich wyrzucaniem, podejmowane w ramach działalności instytucji, organizacji lub ruchów niezależnych w obszarze zaangażowania obywatelskiego, na przykład banki żywności (lub podobne struktury i instytucje w różnych krajach), tak zwany food sharing czy inicjatywy typu food not bombs.

W tym złożonym kontekście cała dziedzina znajduje się jeszcze w fazie (auto) definicji — przy czym nie jest wykluczone, że pozostanie w niej na zawsze właśnie ze względu na swoją specyfikę. W opisanym tu przypadku debata może stanowić szczególnie charakterystyczny element samego zagadnienia. Wskazują na to nie tylko opisana niemożność jednoznacznego określenia jednego, głównego tematu, z którym zjawisko transformation design byłoby/jest powiązane, oraz wynikające z tego trudności przyporządkowania całego obszaru zakresowi zainteresowań wyłącznie jednej dyscypliny naukowej, lecz także odzwierciedlające się w literaturze przedmiotu dyskusje o kwestii nazewnictwa: innym używanym pojęciem (czasem w podobnym, czasem w nieco odmiennym kontekście) jest transition ${ }^{5}$.

${ }^{3} \mathrm{Z}$ tematem i hasłem takim jak zrównoważoność (względnie zrównoważony rozwój) wiąże się z kolei oczywiście dużo więcej, niż da się przedstawić w ramach ogólnej charakterystyki zagadnienia stanowiącego temat niniejszego artykułu. Szczegółową, wieloaspektową analizę pojęcia zrównoważoności przedstawiają: E. Rokicka, W. Woźniak, W kierunku zrównoważonego rozwoju. Koncepcje, interpretacje, konteksty, Łódź 2016, http://socjologia.uni.lodz.pl/pliki/32-w_kierunku_zrownowazonego_rozwoju.pdf (dostęp: 4.11.2017).

${ }_{4}$ Zob. United Nations, Department of Economic and Social Affairs, Sustainable Development, The 17 Goals, https://sdgs.un.org/goals (dostęp: 11.02.2021).

${ }^{5} \mathrm{~W}$ publikacjach naukowych dotyczących zagadnień, które przyporządkować można obszarowi analizy problemów związanych z transformation design, pojawiają się więc obie nazwy (transformation oraz transition). Przy czym zaobserwować można pewne różnice, jeśli chodzi o dokładne ukierunkowanie badań lub o koherencję tekstów opublikowanych pod jednym albo drugim hasłem (na przykład różnice odnośnie do cytowanej literatury oraz współpracujących ze sobą autorów; zob. E.J.L. Chappin, A. Ligtvoet, Transition and transformation: A bibliometric analysis of 
Decydującą różnicę dla przyjętej tu perspektywy stanowi jednak nie tyle pierwszy element nazwy, ile przede wszystkim obecność w niej aspektu projektowego poprzez słowo design, które ( $w$ tu stosowanym, szerokim rozumieniu tego pojęcia) podkreśla aspekt aktywnego kształtowania procesów transformacyjnych w kontekście społeczeństwa i jego środowiska. To ukierunkowanie występuje w obu nazwach, przy czym wersja związana ze słowem transformation/transformacja niekiedy zdaje się także lub po prostu pragmatycznym wyborem podejmowanym w kontekście interkulturowym ze względów językowych ${ }^{6}$.

Jak widać, temat jest niezwykle złożony i obciążony szerokimi kontekstami, których znajomość i akceptacja są konieczne ${ }^{7}$, aby można było nawiązać do niego

two scientific networks researching socio-technical change, „Renewable and Sustainable Energy Reviews" 30, 2014). Według bibliometrycznej/sieciowej analizy porównawczej tych ostatnich, pojęcie transition łączy pewną ściśle powiązaną wspólnotę autorów. Stanowiska na temat transformacji (uwzględnione w analizie) wydają się zaś mniej koherentne, ale jednocześnie w większym stopniu uwzględniające całościowy wymiar zagadnienia. „The majority of the transition literature is linked to sustainability as a normative goal and energy emerged as the dominant topic. [...] In transformation literature, energy and sustainability are often placed within a larger change process, such as economic development, demographics, or the change from a communist to a capitalist society. Also, there seem to be fewer normative, prescriptive approaches and more inquisitive, historical practices" (ibidem, s. 720). Analizując zagadnienie w odniesieniu do zrównoważonej energii, autorzy zwracają uwagę, że taka rozpiętość może być atutem: „The transformation literature teaches us that older streams of thought are still relevant and may be used as "glue « for linking change with respect to sustainable energy to wider developments. Rediscovering existing literature in new combinations may lead to promising new views on sustainable energy" (ibidem, s. 721). W podejściu zaprezentowanym w niniejszej publikacji oraz w wyżej cytowanych pozycjach takie uwzględnienie szerokiej gamy perspektyw jest świadomym wyborem, mającym umożliwić ciągły rozwój obszaru w interdyscyplinarnej debacie.

${ }^{6} \mathrm{Na}$ temat transition design zob. T. Irwin, Transition Design: A Proposal for a New Area of Design Practice, Study, and Research, „Design and Culture”7, 2015, $\mathrm{nr} 2$; T. Irwin et al.,Transition Design 2015, https://design.cmu.edu/sites/default/files/Transition_Design_Monograph_final.pdf (dostęp: 24.06.2018). Dla transformation design — oprócz już wymienionych — na przykład Transformation Design. Perspectives on a New Design Attitude. red. W. Jonas, S. Zerwas, K. von Anshelm, Basel 2015; D. Sangiorgi, Transformative Services and Transformation Design, „International Journal of Design" 5, 2011, nr 2, http://www.ijdesign.org/index.php/IJDesign/article/view/940/344 (dostęp: 2.03.2021). Ilustracją otwartości zagadnienia jest następujący opis pochodzący z jednego ze źródeł (T. Irwin et al., op. cit., s. 10): „Transition Design is an area of design research, practice and study that was conceived at the School of Design at Carnegie Mellon University in 2012 and integrated into new programs and curricula that launched in fall, 2014. However it is presented here as an open source concept and an invitation for engagement and co-evolution with educators, researchers and practitioners from design and related disciplines". Jak widać, również tu występują różnice, jeśli chodzi o główny akcent — niektóre opracowania bardziej podkreślają systemowe (wspomniane społeczno-ekologiczne) aspekty, inne skupiają się na kwestiach socjalnych, dotyczących organizacji lub kwestiach związanych z procesem i teorią projektowania. Wspólną cechą jest jednak interdyscyplinarne, szeroko zakrojone podejście, łączące orientację na zmiany społeczne, najczęściej w kierunku zrównoważonego rozwoju, z kontekstem designu i kształcenia akademickiego.

7 Do ogólnie opisanego bogatego tła w odniesieniu do tematów związanych z transformation design przynależy także niezmiernie ważna działalność w zakresie szerszego, opartego na nauko- 
w komunikacjach. To przysparza kilku zasadniczych problemów, zarówno tym, którzy podejmują je w ramach nauki, ze względu na wymagane przy nim interdyscyplinarne podejście, jak i tym, którzy aktywnie kształtują zmianę poprzez swoją konkretną działalność.

Niniejszy tekst ma na celu krótkie naszkicowanie problemu i rozważenie zagadnienia na dwojakim tle. Po pierwsze, na tle teoretycznym, opartym na analizie normalności w komunikacjach oraz na stratyfikacji komunikacji/społeczeństwa na grupy społeczne i ich quasi-dyskursy, subkultury i dyskursy, a także na społeczeństwo i jego interdyskurs (co niżej zostanie krótko omówione). Po drugie, na tle praktyczno-doświadczalnym, za pomocą maksymalnie otwartego, eksperymentalnego scenariusza warsztatów. Warsztaty te mogą zarówno zostać wykorzystane jako narzędzie strategiczne przy wprowadzaniu tematu do komunikacji, jak i służyć empirycznej obserwacji procesów systematyzacji wiedzy i informacji oraz, ogólniej, zbadaniu kwestii (nie)komunikowalności ${ }^{8} \mathrm{w}$ odniesieniu do zagadnień związanych z projektowaniem zmian, które to kwestie do tej pory nie zostały jeszcze zbadane empirycznie 9 .

Normalność w komunikacji odnosi się — na tle teorii komunikacji Michaela Fleischera ${ }^{10}$ oraz normalizmu Jürgena Linka ${ }^{11}$ — do kwestii wzajemnych oczekiwań dotyczących tego, co uznane jest za normalne, zwykłe, wchodzące w grę, niewymagające wyjaśnień lub uzasadnień. Nie mamy zatem do czynienia z normami i normatywizmami jedynie (które stanowią jedną, szczególnie drastyczną formę ograniczania pól normalnościowych w komunikacjach), lecz z ciągle odbywającym się w społeczeństwie procesem negocjowania tego, jak chcemy zor-

wych badaniach, komunikowania zasadniczych problemów wyjściowych związanych z globalnym ociepleniem i zmianami klimatycznymi, zob. M. Popkiewicz, A. Kardaś, S. Malinowski, Nauka o klimacie. Mechanizmy działania systemu klimatycznego. Zmiany klimatu w przeszłości i obecnie, Warszawa 2019; oraz https://naukaoklimacie.pl/, zob. też https://skepticalscience.com/ (dostęp: 2.03.2021).

${ }^{8} \mathrm{Na}$ temat zjawiska niekomunikowalności na poziomie teoretyczno-analitycznym zob. M. Fleischer, Konstrukcja rzeczywistości 3, Kraków 2017, s. 221-241; orazidem, Niekomunikowalność, [w:] Język i tekst w ujęciu strukturalnym i funkcjonalnym, red. A. Dudziak, J. Orzechowska, Olsztyn 2017.

9 Publikacje nawiązujące w kontekście tematów związanych z projektowaniem transformacji do aspektu komunikacji mają zaś zazwyczaj charakter doradczy, czyli dotyczą najwyżej rozważań strategicznych dla wybranych tematów szczegółowych, a nie zjawiska/problemu ogólnego, zob. na przykład Ontario Biodiversity Council, Communicating Biodiversity \& Climate Change. A Guide for Crafting Effective Messaging, Ontario 2017, http://ontariobiodiversitycouncil.ca/wp-content/ uploads/Biodiversity-and-ClimateChange-August2017.pdf (dostęp: 11.02.2021).

10 M. Fleischer, Ogólna teoria komunikacji, Wrocław 2007.

11 J. Link, Normalismus. Konturen eines Konzepts, ,,kultuRRevolution Zeitschschrift für angewandte Diskurstheorie" 1992, nr 27; idem, Versuch über den Normalismus. Wie Normalität produziert wird, Opladen 1998; idem, Normale Krisen? Normalismus und die Krise der Gegenwart, Konstanz 2013; 'Normalität' im Diskursnetz soziologischer Begriffe, red. J. Link, T. Loer, H. Neuendorff, Heidelberg 2003. 
ganizować wspólnie używany zasób znaków i znaczeń z nimi związanych oraz, by tak rzec, co na jakim miejscu sytuuje się w ramach tego zasobu w odniesieniu do pozostałych elementów. Do konstrukcji (potwierdzania, sugestii modyfikacji itp.) tych powiązań służą nam — z perspektywy analizy normalności w komunikacji — procedury normalizacyjne i odpowiednie zabiegi (na przykład kwalifikowanie czegoś jako normalne/nienormalne właśnie, mówienie o czymś, że jest zaskakująco duże, małe, nowe, dziwne) ${ }^{12}$. Komunikując, generujemy i negocjujemy w ten sposób obszary normalnościowe odnośnie do pojawiających się zagadnień, to jest pola tego, do czego można w wypowiedziach nawiązać bez dłuższego wyjaśniania sprawy lub bez argumentacji. Jeśli spojrzeć na rzecz systemowo, ma to tę zaletę, że na tych wspólnie negocjowanych założeniach normalnościowych można polegać, a tę wadę — że to, co nowe, ma wyższy próg do pokonania, nim może nie tylko przejściowo się pojawić, lecz także ustabilizować w komunikacji. Szerszym tłem teoretycznym dla tych — tu, ze względu na charakter tekstu, tylko krótko naszkicowanych — zagadnień jest więc aspekt nawiązywalności i jej kluczowej roli w komunikacji, opisany przez Michaela Fleischera w Ogólnej teorii komunikacji, opartej na konstruktywistycznej teorii systemów Niklasa Luhmanna ${ }^{13}$.

Również tematy związane z transformation design muszą być siłą rzeczy odnoszone „do czegoś”, by mogły się w ogóle pojawić (czy to w codziennej rozmowie, w komunikacji medialnej, czy w kontekście naukowym), na przykład do obszaru „eko” lub „ekologii”, „alternatywy”, zaangażowania obywatelskiego, względnie do odpowiedniego elementu dyskursu specjalistycznego. Będą one, również siłą rzeczy, asymilowane w tych już wcześniej ustalonych ramach dyskursowych na tle odpowiednich oczekiwań normalnościowych, które są aktualizowane wraz z tymi ramami (framing) ${ }^{14}$, tyle że od strony komunikacji i stojących do jej dyspozycji szablonów i scenariuszy. Opisane tu aspekty dotyczą komunikacji ogólnie, to znaczy stanowią z teoretycznego punktu widzenia integralny, funkcjonalny element mechanizmu negocjowania znaczeń, a ich (zawsze przejściowe) rezultaty stają się jednocześnie obserwowalne empirycznie, gdyż manifestują się w wypowiedziach. Z równie szerokiej perspektywy rozróżniać można w teorii komunikacji następującą stratyfikację społeczno-komunikacyjną ${ }^{15}$ :

1. Quasi-dyskursy tworzone są w grupach przyjaciół, wśród studentek/studentów lub pracowników w miejscu pracy, w rodzinie. Na tym poziomie panuje największy stopień wolności odnośnie do ograniczeń normalnościowych — nowe

12 Szczegółowa analiza zagadnienia zob. A. Siemes, Normalność z perspektywy obserwatoradiagnoza, Łódź 2015.

13 Zob. Radykalny konstruktywizm. Antologia, red. B. Balicki et al., Wrocław 2010.

14 O różnych ujęciach odnośnie do tego pojęcia względnie związanego z nim paradygmatu zob. R.M. Entman, Framing: Towards clarification of a Fractured Paradigm, [w:] McQuail's Reader in Mass Communication Theory, red. D. McQuail, London 2002.

15 Szczegóły zob. M. Fleischer, A. Siemes, Świadomość i przynależność subkulturowa wśród młodzieży, [w:] Badanie komunikacji / projektowanie komunikacji, t. 3, red. M. Grech et al., Kraków 2020, s. 19-24. 
elementy mogą być swobodnie wprowadzane, prawie dowolnie modyfikowane, ale mogą też szybko znikać. Coś, co zostało ustalone nie ,przez nas”, obowiązuje tu w niskim stopniu.

2. Dyskursy wygenerowane w supragrupach (w teorii też określanych jako subkultury) mają już większą stabilność oraz solidniejszą i bardziej obowiązującą bazę przez wsparcie w stojących za nimi większych formacjach społecznych.

Dyskurs to systemowy repertuar interpretantów ( $\approx$ znaczeń) wraz z organizującymi ten repertuar regułami i normami generującymi i użytkowymi komunikacji danej formacji społecznej, stanowiący o komunikacyjnej i społecznej specyfice tej formacji. Innymi słowy: dyskurs jest komunikacyjnie uwarunkowanym społecznym sposobem tego, jak i za pomocą jakich interpretantów dana subkultura zabiera głos w komunikacjach, zapewniając sobie tym w systemie społecznym swą spójność (koherencję). Dyskurs kreuje rzeczywistość komunikacyjną danej formacji i zapewnia jej dyskretność (wyróżnialność) ${ }^{16}$.

Komunikacje (na przykład informacje dotyczące projektowania transformacji ogólnie lub poszczególnych aktywności w jego zakresie) na tym poziomie mogą się rozprzestrzeniać szybko i stabilizować w ramach danej subkultury lub w obrębie dyskursów specjalistycznych.

Opisany poniżej eksperymentalny warsztat odbył się na pograniczu pierwszego i drugiego poziomu (przy czym warto zwrócić uwagę, że nie mamy tu do czynienia $\mathrm{z}$ hierarchią, lecz jedynie $\mathrm{z}$ podziałem i opisem funkcjonalnym).

3. Społeczeństwo i jego interdyskurs to zaś główne miejsce negocjowania normalności. Tu najtrudniej jest wprowadzać coś nowego, wymaga to większego wysiłku negocjacyjnego, gdyż baza, do której wejść mają nowe elementy, jest maksymalnie złożona oraz (w porównaniu z pierwszym i drugim poziomem) mocna i stabilna ${ }^{17}$.

$\mathrm{Na}$ tle opisanej dyferencjacji komunikacji zasadniczym problemem w zakresie analizy koncepcji oraz aktywności z obszaru transformation design — zwłaszcza małych inicjatyw na poziomie mikro - są gromadzenie i systematyzacja (oraz, z punktu widzenia uczestników konkretnych inicjatyw, rozszerzenie) informacji nie tylko o istnieniu danych idei, lecz także o samych ideach i stojących za nimi ideach głównych. Nie wspominając już o kompleksowej problematyce ogólnej w tle, którą również trzeba znać, aby w ogóle dostrzec rację bytu danego ruchu. Z punktu widzenia teorii komunikacji (jak i systemu społecznego) odpowiednie inicjatywy sytuują się przeważnie w niszach komunikacyjnych i są - im mniejsze, tym bardziej — ograniczone do swoich quasi-dyskursów lub - co najwyżej — do dyskursu danej subkultury, w której obrębie mogą realizować tematy tego dyskursu (na przykład ekologiczne, specjalistyczne w kontekście naukowym). To umożliwia im, co prawda, sprawne funkcjonowanie na tym poziomie, w modusie wewnętrznym. Próg do przejścia w interdyskurs, a zatem pojawienia się

16 Ibidem, s. 23.

17 Tę stabilność można obserwować na przykładzie symboli kolektywnych, zob. M. Fleischer, A. Siemes, M. Grech, Stabilność polskiej i niemieckiej symboliki kolektywnej, Wrocław-Kraków 2021. 
w szerszym kontekście (społecznym, medialnym), pozostaje jednak wysoki ${ }^{18}$. Takie przejście — i to kolejny problem na ogólniejszym tle komunikacji — dodatkowo hamowane jest przez procedury normalizacyjne, które zabezpieczają komunikację na tym ogólnym poziomie (interdyskursu), chroniąc go przed zbyt nagłymi i drastycznymi (lub pochopnymi) zmianami ${ }^{19}$. Generowanie nawiązywalności i możliwość aktualizacji danego tematu w ramach już istniejących oczekiwań normalnościowych (choćby w tym względzie, że ów nowy, do tej pory nieporuszany temat stanowi jednak alternatywę dla czegoś już istniejącego) to swego rodzaju bilet wstępu do interdyskursu. Jak więc w komunikacji coś, co wskazuje na możliwości zmian, co stanowi propozycję robienia czegoś (nierzadko — zupełnie) inaczej, może w ogóle pojawić się na poziomie interdyskursu i stać się tematem szerszej debaty społecznej? Ani w transformation design, ani w niniejszym tekście nie chodzi bowiem o wprowadzenie czy wręcz przeforsowanie jednej opcji czy wersji zmian, preferowanej i sugerowanej przez jakąś grupę czy formację społeczną. Chodzi o szerszy problem komunikacyjny, a mianowicie: czy i jak coś, co sugeruje (w pewnym sensie — jakąkolwiek) zmianę systemową, może stać się tematem komunikacji traktowanym równorzędnie z innymi wątkami, już funkcjonującymi w komunikacji.

Kolejnym wyzwaniem - zarówno dla naukowej analizy, jak i dla samego procesu komunikowania zagadnień z zakresu transformation design — jest prezentacja złożonych, kompleksowo ze sobą powiązanych informacji na ich temat i wskazanie na ich usieciowienie. Tą kwestią zajmowałam się bardziej szczegółowo w publikacji książkowej Transformation design w kontekście projektowania komunikacji i badań normalności, w której usystematyzowałam wybrane zagadnienia, nie tylko tematycznie, lecz także w odniesieniu do szerszych kontekstów istotnych dla określonych grup (wyróżnione kolorem) oraz ze względu na ich charakter ogólny (poziom makro/mezo/mikro — zob. rysunek 1). Kilkadziesiąt haseł z tego przeglądu zostało omówionych w tej książce w glosarium, gdzie pod każdym hasłem wskazane zostały przykładowe pokrewne hasła ${ }^{20}$.

18 To, jak manifestuje się przejście (lub jego brak) odpowiednich tematów w interdyskurs, obserwować można między innymi za pomocą badań empirycznych — dotyczących na przykład wizerunku wybranych supragrup/subkultur (zob. A. Ciążela, Postrzeganie osób dbających o środowisko przez młodych Polaków, „Studia Ecologiae et Bioethicae” 13, 2015, nr 4) - lub też, szerzej, za pomocą wprowadzania pewnych tematów w konteksty medialno-komunikacyjne. Zob. A. Siemes, Kryzys jako stan normalny - o normalizacji rzeczy nie do przyjęcia. Zarys projektu badawczego, [w:] Autopromocja, autoprezentacja, wizerunek w komunikowaniu masowym, t. 5. Bład, kryzys, skandal, red. E. Biłas-Pleszak, A. Kalisz, E. Tyc, Katowice 2019; oraz eadem, Kto ma naprawić świat? Badanie na temat globalnego ocieplenia oraz szczytu klimatycznego COP24 w Katowicach, [w:] Badanie komunikacji / Projektowanie komunikacji, t. 3, red. M. Grech et al., Wrocław-Kraków 2020; dla egzemplifikacji sytuacji ilustrujących nie ma takiej możliwości, zob. wstęp filmu dokumentalnego na temat zmian klimatycznych Można panikować (reż. J.L. Ramsey, 2020), https://www.moznapanikowac.pl/ (dostęp: 2.03.2021).

19 Więcej o normalizacji i normalności w komunikacjach zob. A. Siemes, Normalność...

20 Zob. A. Siemes, Transformation design w kontekście projektowania ..., s. 84-85. 


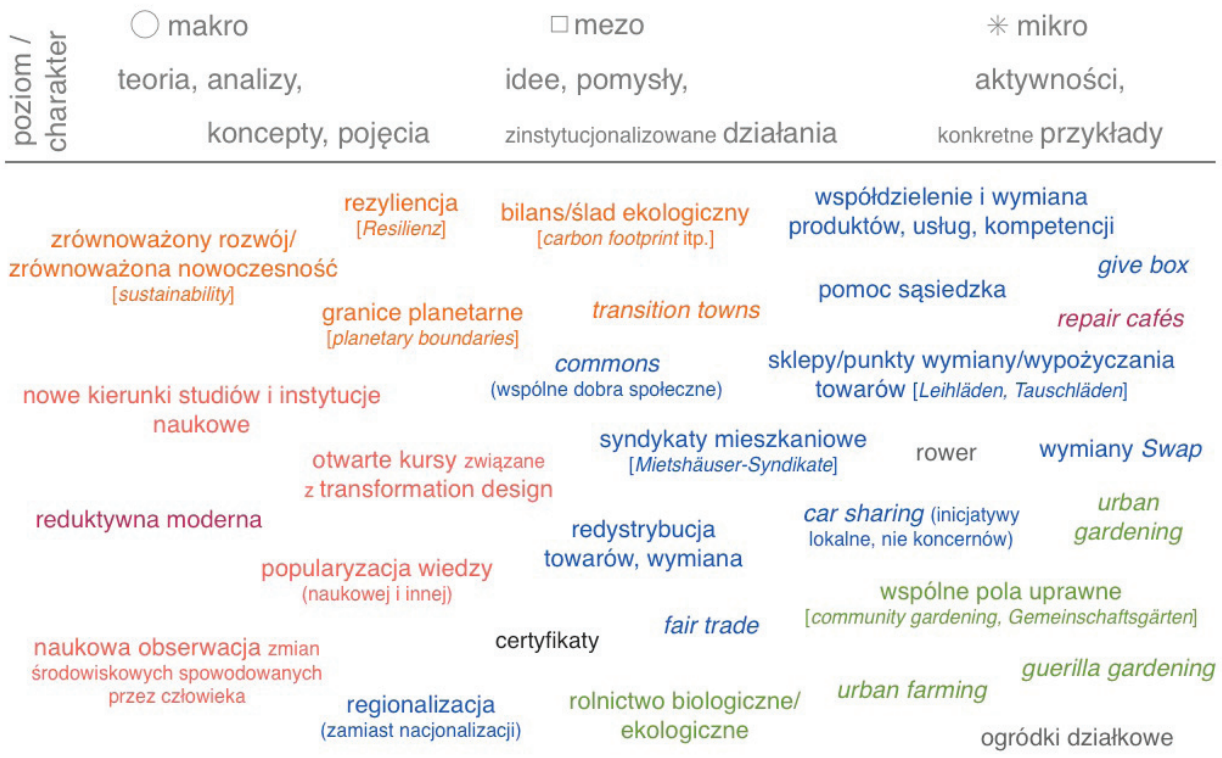

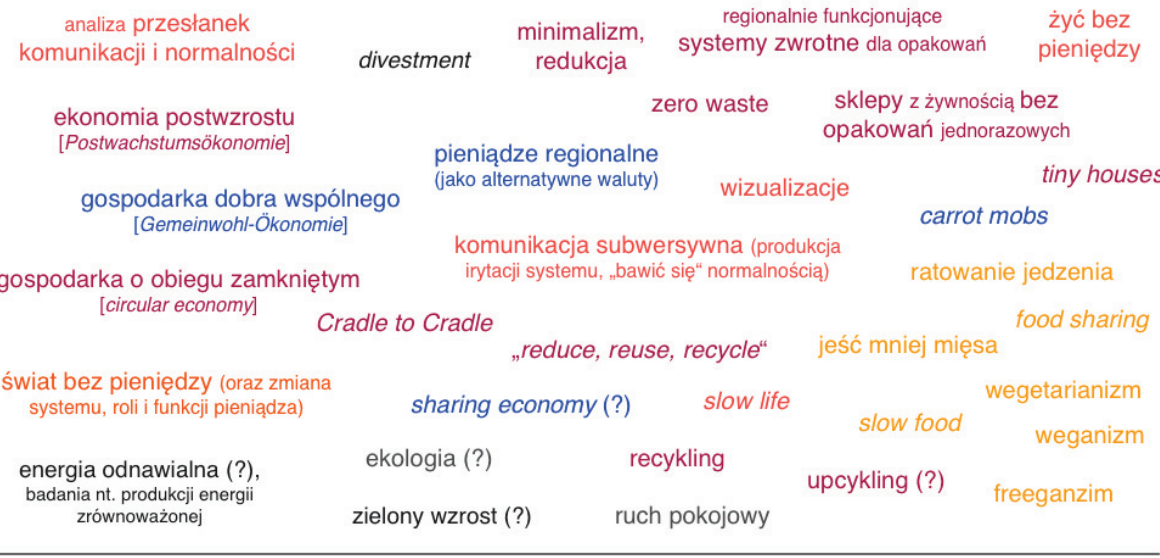

legenda dla kolorów - rodzaj koncepcji, inicjatyw, aktywności:

$\begin{array}{lll}\text { koncepcje podstawowe } & \text { inicjatywy społeczne, sąsiedzkie } & \text { idee historyczne } \\ \text { podejścia dot. komunikacji i normalności } & \text { inicjatywy dot. produkcji żywności i zieleni } & \text { szersze tematy bez klasyfikacji } \\ \text { koncepcje redukcji i cykliczności } & \text { koncepcje dot. odżywiania } & \text { *jeden z wielu możliwych podziałów }\end{array}$

Rysunek 1. Przegląd haseł dotyczących przykładowych koncepcji i inicjatyw w zakresie transformation design

Źródło: opracowanie własne.

Wybrane hasła i pojęcia z zakresu transformation design stały się także punktem wyjścia do opracowania zestawu materiałów do badania eksploracyjnego w formie swego rodzaju eksperymentu. Ogólnym celem, na tle naszkicowa- 
nego kontekstu problemowo-poznawczego, były praktyczne zastosowanie oraz przetestowanie (umyślnie możliwie prostej) metody wprowadzania nowych pojęć w nowe, jeszcze nie ustalone ramy komunikacyjne. Eksperyment polegał na przygotowaniu zestawu kart $\mathrm{z}$ hasłami i zaprezentowaniu takich (na razie) bezkontekstowych haseł czy pojęć stosownym grupom (uczestnikom konferencji i studentom), aby wymusić tym samym proces asymilacji tych haseł poprzez generowanie kontekstów, a w rezultacie wiedzy. Wcześniej opracowany zestaw kart na temat transformation design stanowił tym samym podstawę do rozmów, dyskusji, gry, przemyśleń, szkicowania projektów, przez co rozszerzał w trakcie takiej procedury wiedzę i informacje w sposób kooperatywny oraz umożliwiał badaczowi śledzenie procesu negocjowania znaczeń, powiązań tematycznych, widzianych oraz niewidzianych kontekstów itp. Zestaw taki został przeze mnie eksperymentalnie zastosowany na różnych spotkaniach o charakterze naukowym i dydaktycznym (na konferencji naukowej oraz na warsztatach czy w ramach ćwiczeń ze studentami), co jednak nie oznacza, że nie mógłby zostać zastosowany w zupełnie innych sytuacjach lub/i na różne sposoby. Stworzenie zestawu jest proste — na osobnych kartkach notuje się szereg pojęć i określeń odnoszących się do transformation design. Mogą to jednak być, w odróżnieniu od zaprezentowanego przeglądu, zarówno podstawowe problemy, jak i podejścia i inicjatywy pokazane na ilustracji (rysunek 1) lub inne hasła związane z tematem, który rozwija się tak dynamicznie, że wymagana jest elastyczność. Zestaw zatem nie jest stały, a do jego produkcji wybrano najprostsze metody pozwalające na jego stałe rozszerzanie. Kartki można na przykład wykonać z kartonu, który w przeciwnym wypadku byłby wyrzucany; tak jak się stało w opisanej tu sytuacji, co jednocześnie dało możliwość żywego zilustrowania tematu upcyklingu. Kilka kartek można zostawić pustych, aby tym samym zaoferować uczestnikom możliwość dodawania własnych haseł. Wykorzystany przeze mnie zestaw zawierał około 90 kartek ( 80 z hasłami/pojęciami i dziesięć pustych), nie licząc dodatkowych notatek uczestników na samoprzylepnych kartkach (gdyż kartek kartonowych w ciągu dyskusji z reguły nie wystarczało).

To, co odróżnia korzystanie $\mathrm{z}$ takich kartek od tradycyjnych form dydaktycznych tego typu, jest banalne, ale, jak się okazuje, komunikacyjnie oraz badawczo ciekawe. To mianowicie brak planu i (o ile to możliwe) oczekiwań. Wszystko poza wstępnym przedstawieniem zestawu i wylosowaniem kilku kartek przez każdego uczestnika spotkania - można ustalać w danej sytuacji (lub też próbować pracować bez ustaleń). Kartki z pojęciami i hasłami są jedynym odgórnie przygotowanym i zaprojektowanym bodźcem. Reszta zależy od dnia, miejsca oraz, przede wszystkim, od samych uczestników przedsięwzięcia — na przykład czy już po rozdaniu kartek rozwinie się dyskusja w całej grupie, czy wytworzą się podgrupy, czy też uczestnicy potraktują kartki jako zestaw do jakiejś gry i będą starali się znaleźć jej reguły, czy wreszcie uznają rzecz za zaproszenie do dyskusji, do dzielenia się wiedzą, zadawania pytań albo projektowania inicjatyw. 

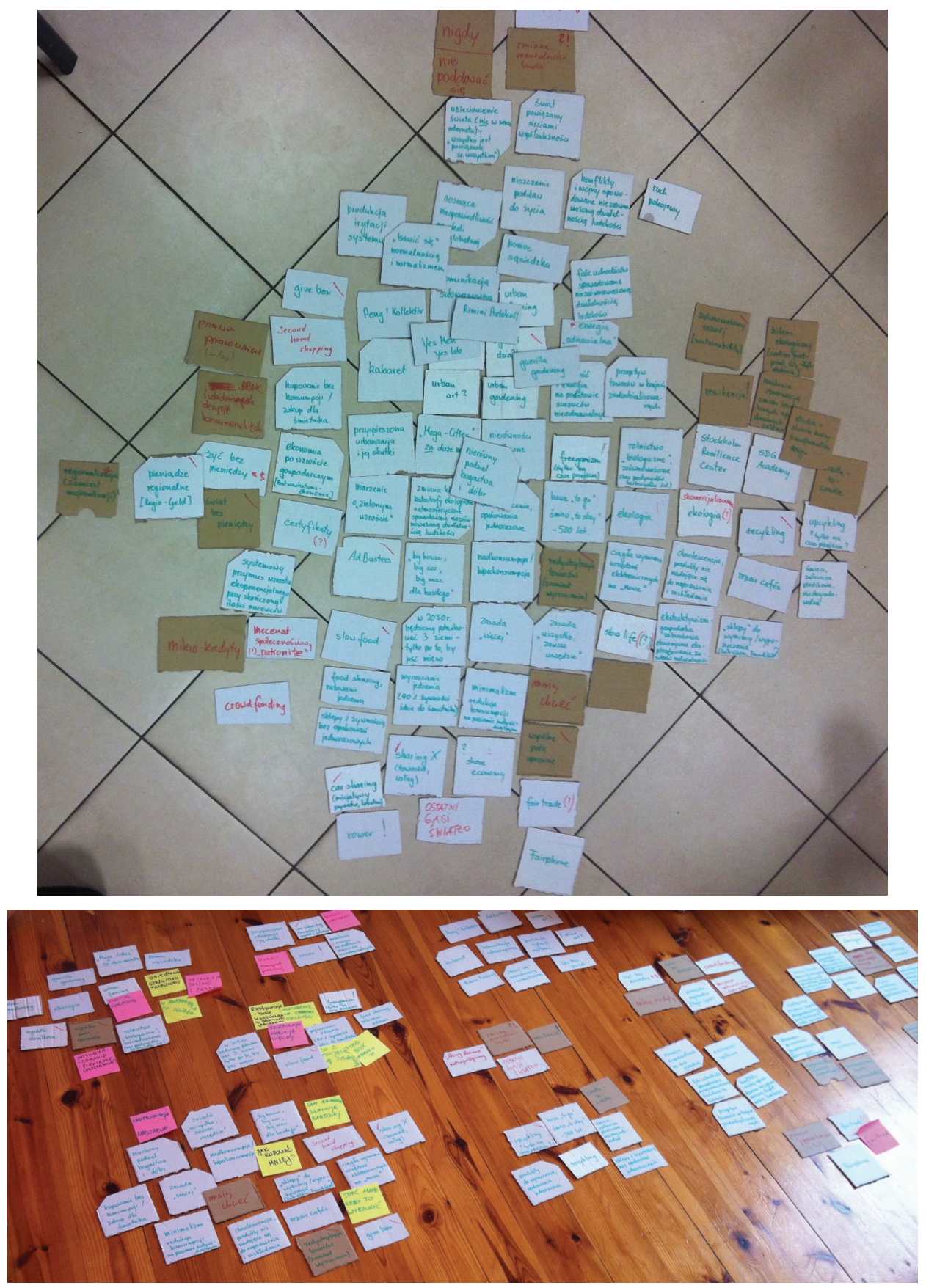

Fotografia 1 i 2 . Dwa przykłady pełnego zestawu kartek użytego w ramach różnych warsztatów Źródło: zdjęcia własne. 
Już obserwacje dotyczące sposobu obchodzenia się z taką sytuacją, której charakter nie jest na wstępie odgórnie ustalony przez jakiś istniejący scenariusz, niezależnie od kwestii transformation design, stanowią ciekawy materiał badawczy. Jednym z wyników pierwszej próby korzystania z zestawu w ramach warsztatów na konferencji była obserwacja, że według uczestników powinien być znany wynik (docelowy „produkt” końcowy). Organizowali się oni w grupach około pięcioosobowych, w których próbowali w żywej dyskusji układać i systematyzować kartki, przy czym wcześniej wręcz domagali się ustalenia (najpierw ode mnie, a kiedy odmówiłam - wspólnie) pewnych zasad i jakiegoś celu. W rezultacie wspólnie ustaliliśmy cel szukania i uzyskania informacji o hasłach — wyjaśnienie pojęć zanotowanych na kartkach oraz próba ustalenia powiązań między nimi z możliwością generowania i dodawania własnych pomysłów i pojęć. Dalsza procedura dojścia do tego celu rozwijała się jednak dynamicznie w procesie samoorganizacji uczestników. Przebieg warsztatów można zrekonstruować następująco: 1. praca w osobnych małych grupach nad wybranymi, zdaniem uczestników, odpowiadającymi sobie w jakiejś mierze, kartkami; 2. indywidualne rozmowy grup między sobą według własnych scenariuszy. Jako dodatkowy, logiczny krok, szczególnie sensowny w kontekście zajęć ze studentami, warto oczywiście dodać punkt 3 dyskusję i podsumowanie w całej grupie. Można było zauważyć, że po krótkim podsumowaniu dyskusja toczyła się dalej w mniejszych grupach, których skład się zmieniał w porównaniu z pierwotnym układem. Jak widać, postępowanie ogólnie odpowiadało więc typowemu schematowi przebiegu warsztatów lub dyskusji grupowych, z tą różnicą, że na początku wydarzenia teoretycznie były do dyspozycji różne opcje. Spośród nich jednak wybrana została ta, która odpowiadała oczekiwaniom normalnościowym dotyczącym tego typu wydarzeń właśnie.

Taka metoda stosunkowo samodzielnego ustalania procedur nie jest oczywista ani łatwa, nie pozwala też na wycofanie się z odpowiedzialności za dalszy przebieg wydarzenia. Ramy normalnościowe i ogólny scenariusz komunikacyjny wydarzeń typu warsztaty przewidują bowiem odgórne narzucanie reguł gry przez prowadzącego. Brak jasno określonych zasad na początku spotkania warsztatowego spowodował zatem pewne niezadowolenie wśród uczestników, u niektórych idące tak daleko, że (jak później referowali) najpierw zastanawiali się nad rezygnacją z uczestnictwa, a potem tym bardziej angażowali się i byli zadowoleni z uczestnictwa w stosunkowo autonomicznie przez nich samych zorganizowanym procesie. Okazuje się zatem, że brak informacji, względnie wymóg samodzielnej organizacji stosownych procesów komunikacyjnych, by informacje samemu wygenerować, może być sprawnym narzędziem (czy raczej — bodźcem) do aktywacji uczestników oraz, tym samym, narzędziem uruchamiania aktywnie kształtowanych procesów negocjacji znaczeń — pod warunkiem, że mamy szansę zatrzymać uczestników do czasu uruchomienia procesu samoorganizacji. Natomiast w sytuacjach, w których istnieje możliwość ucieczki, narzędzie to jest nieadekwatne. Tego typu 
wydarzenia, czyli pozbawione ram zewnętrznych, jakie podają nam studia, konferencja itp., należałoby zaprojektować odgórnie i zastosować scenariusz z możliwie otwartym wstępem, niesugerującym konkretnego kierunku i sposobu działania, ale jednak oferującym ramy potrzebne do podejmowania jakiejkolwiek dyskusji. Wtedy jednak zagadnienie utraciłoby charakter eksperymentu.

Konieczność samodzielnego ustalenia reguł na miejscu była bowiem jednym z niewielu założeń wstępnych. Scenariuszem był, by tak rzec, brak scenariusza, gdyż z analizy roli normalności i procedur normalizacyjnych w komunikacji wynika, że oferowanie gotowego scenariusza prowadzi do asymilacji tematów komunikacji w jego ramach. Oznacza to, że gdyby zasady korzystania z zestawu były dokładniej określone i z góry ustalone, pojęcia zanotowane na kartkach zostałyby natychmiast zintegrowane w pasujący kontekst normalności. Straciłyby wtedy jednak — taka była przynajmniej teza — swoją moc uruchomienia pewnej dynamiki i negocjowania semantyki lub, dokładniej, znaczenia komunikacyjnego. Mogłyby bowiem być widziane tylko i wyłącznie jako arbitralny materiał służący do realizacji pewnego scenariusza (gry, dyskusji grupowej itp. — w zależności od tego, jaki model byłby właśnie na wstępie podany), który równie dobrze mógłby być inny. Grupa co prawda i tak wybrała sobie scenariusz (idący w stronę dyskusji grupowej) — z tą jednak różnicą, że musiała go sama utworzyć i tym samym otworzyła sobie nowe możliwości tworzenia relacji między hasłami. Podejście to ma także zaletę pod względem dydaktycznym: zwiększa się wtedy uważność w stosunku do własnej roli w kontekście tego, co się dzieje.

Dyskusja, która powstała w ramach pierwszego warsztatu przeprowadzonego na konferencji, odbywała się przeważnie w spontanicznie stworzonych, mniejszych grupach i trwała około dwóch godzin, a zakończona została raczej z uwagi na późną porę niż z powodu wyczerpania tematu. Konkretne podejścia w podgrupach były różne: niektóre skupiały się na dzieleniu się wiedzą, inne raczej na wstępnym projektowaniu konkretnych rozwiązań, w jeszcze innych rozmowa dotyczyła bardziej kompleksowych problemów i globalnych zagadnień z zakresu transformation design. Wnioski w związku z tym były różne, o czym dowiedzieli się jednak tylko ci uczestnicy, którzy w czasie trwania spotkania zmieniali grupy. Dla przyszłych zastosowań zestawu haseł można by przemyśleć, czy jako punkt ramowy nie dodać jednak konieczności podsumowania pracy oraz dyskusji końcowej już na forum. Fotografie 3-8 dokumentują sytuację korzystania z zestawu.

W ramach ćwiczeń ze studentami zestaw został w ostatnich trzech latach kilkakrotnie wykorzystany w różnych grupach liczących około 20 osób, jako wstęp do zajęć. Temat zatem — transformation design — podany był na wejściu, pozostałe aspekty, to znaczy dokładny scenariusz realizacji warsztatu, pozostały również w tym przypadku możliwie otwarte i nieokreślone. Zadanie polegało tylko na tym, aby ze znajdującym się na stole materiałem (pudełko z kartkami), w określonym czasie (z reguły 1,5 godziny) zrobić coś, co uczestnicy uznają za „sensowne” 

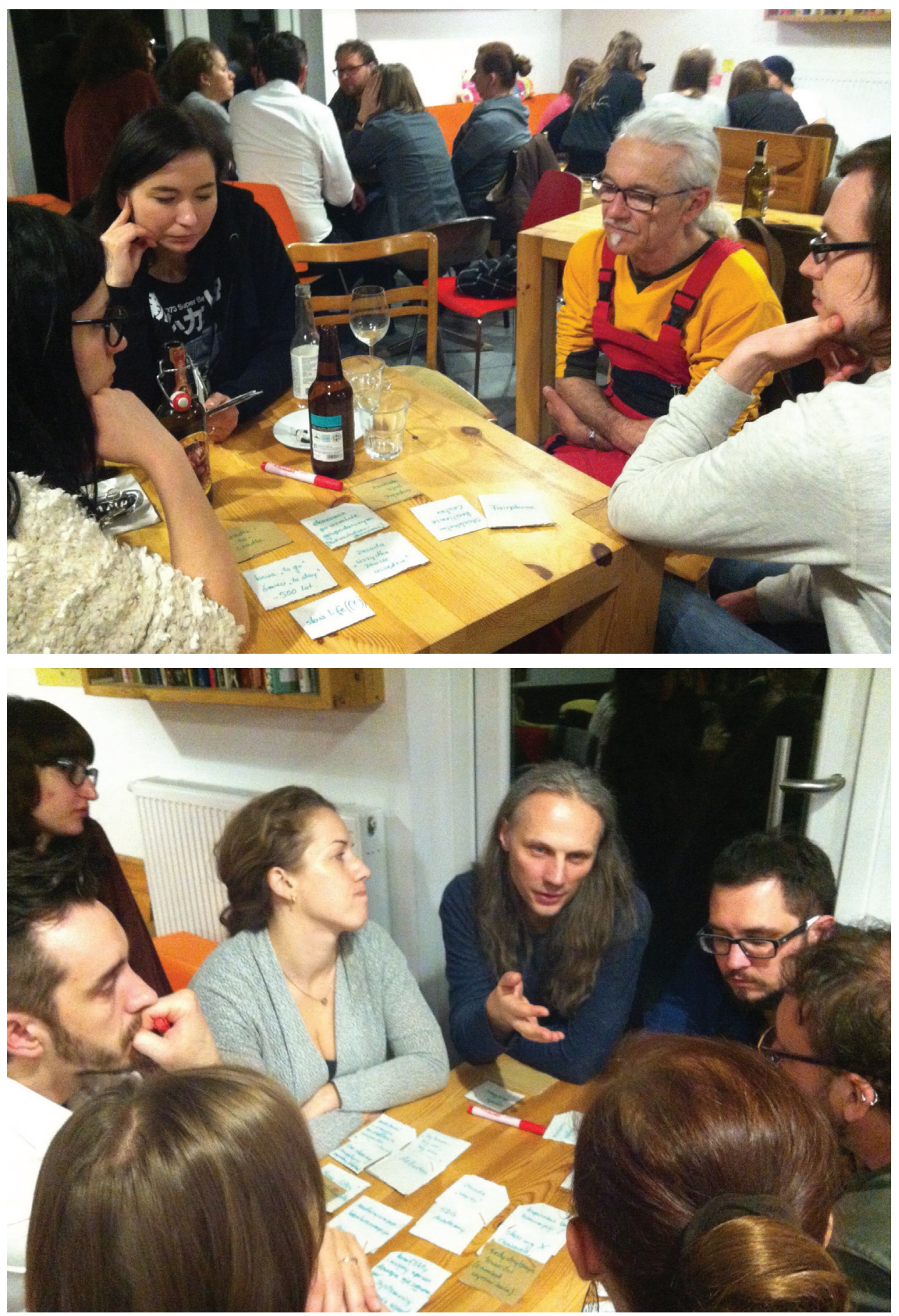

Studenckie Prace Prawnicze, Administratywistyczne i Ekonomiczne 38, 2021 (C) for this edition by CNS 

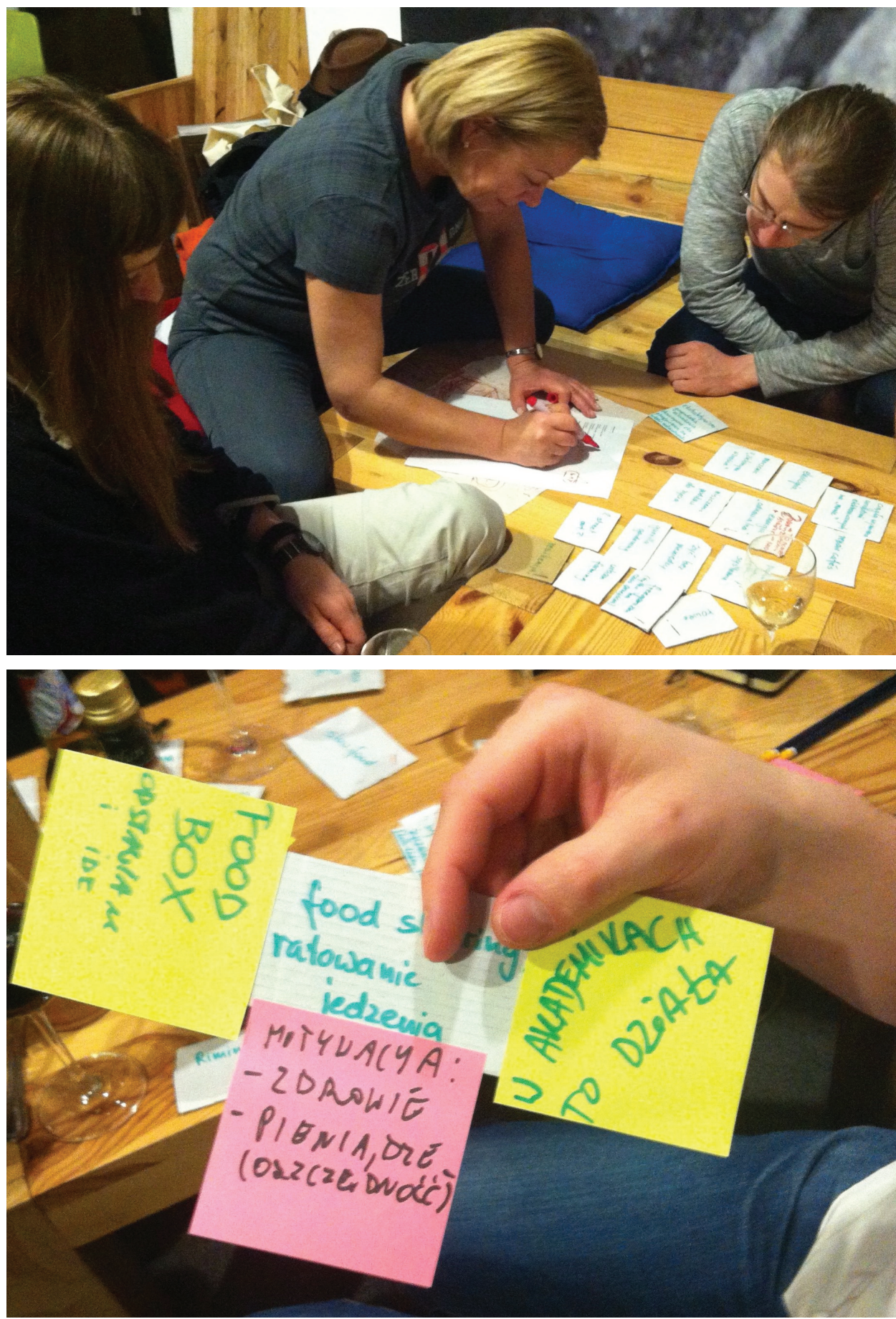

Studenckie Prace Prawnicze, Administratywistyczne i Ekonomiczne 38, 2021 (C) for this edition by CNS 

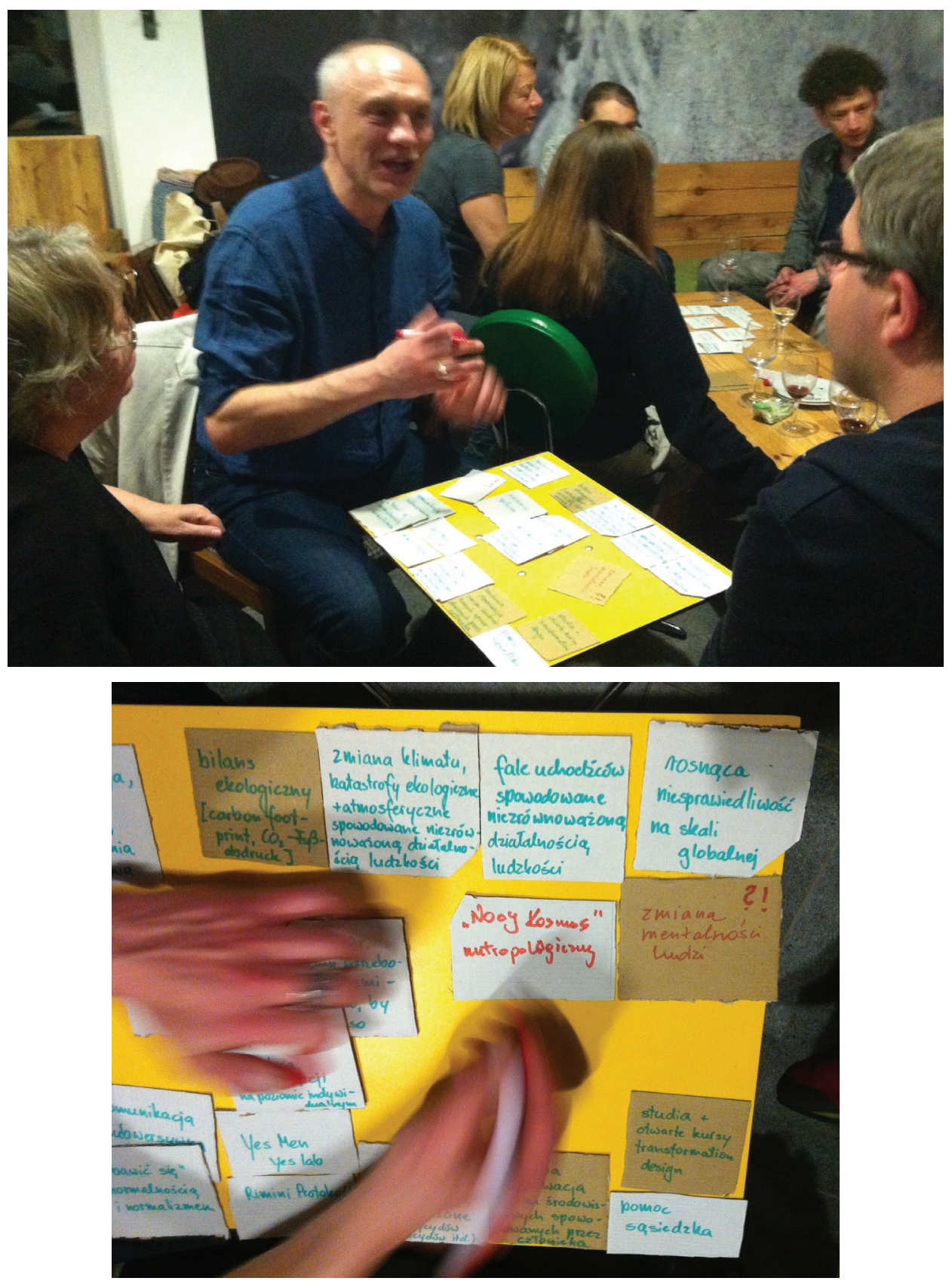

Fotografie 3-8. Autopoiesis od podstaw - samoorganizująca się praca z zestawem kart na temat transformation design, konferencja Communication design - badanie i projektowanie komunikacji 7, Podlesice, kwiecień 2017

Źródło: zdjęcia własne. 
(użyte zostało tylko takie polecenie, umyślnie bez dalszych dodatków typu „w kontekście zajęć/tematu").

Również studenci wybrali przeważnie opcję pracy w mniejszych grupach, w których konstruowali (a nie tylko rekonstruowali) powiązania między różnymi tematami, informowali się wzajemnie o nich, jeśli ktoś posiadł specjalistyczną wiedzę itp. Wybrane zostały więc formy pracy polegające na kooperacji oraz dzieleniu się wiedzą, przy czym jednak uczestnicy pozostawali w ramach, jakie przewiduje dla takich sytuacji kontekst formalny (konferencja, ćwiczenia), to znaczy nie odeszli od ogólnych scenariuszy związanych z miejscem i czasem. Żadna z dotychczas przebadanych grup nie próbowała wyjść z tych ram, na przykład wymyślić własnych reguł lub innych form wykorzystania kart (takich jak gra, zawody).

Praktyczne wnioski wynikające $\mathrm{z}$ opisanego tu pierwszego, eksploracyjnego etapu stosowania zestawu kart odnoszą się do aspektów materiałowych oraz do możliwości dokumentacji wyników i związanych z tym trudności. O ile dokumentacja fotograficzna (rozłożonych na stole kartek w poszczególnych fazach eksperymentu) jest jeszcze stosunkowo łatwa, o tyle, zwłaszcza przy niedookreślonych warunkach ramowych, obserwacja i śledzenie procesów prowadzących do efektu końcowego są niezwykle trudne. Tradycyjnie stosowane w takiej sytuacji nagranie filmowe jest nieadekwatne nie tylko ze względów technicznych, lecz także z powodu wpływu tego narzędzia na zachowania uczestników, którzy nie czują się wtedy zwykle swobodnie. Jedyną możliwością, która w ramach większych badań wymagających bardziej systematycznej i dokładnej dokumentacji wchodziłaby w grę, byłyby praca $\mathrm{z}$ udziałem kilku obserwatorów oraz sporządzenie dzienników badawczych. Technika ta ma oczywiście sporo wad i generuje kolejne trudności z uwagi na spójność wyników. $Z$ kolei do samego zestawu można by dodać, co pokazały dotychczas przeprowadzone eksperymenty, więcej pustych kartek. Można by też wzbogacić materiały pomocnicze (na przykład o klej, taśmę klejącą czy różnokolorową nić), umożliwiające i sugerujące jeszcze bardziej kreatywne rozwiązania w zakresie tworzenia relacji.

Przedstawiony tu projekt eksperymentalnych warsztatów nie stanowi oczywiście gotowej propozycji dla kolejnych badań empirycznych; na tym etapie spełnia co najwyżej funkcję ilustrującą możliwość rekonstruowania procesu systematyzacji wiedzy (tu - na temat transformation design) oraz wprowadzania (w mniejszym lub większym stopniu) nowych tematów czy zagadnień w szersze konteksty komunikacji, w relacji do powstających przy tym problemów dotyczących ogólnego systemowego charakteru komunikacji, jej stratyfikacji oraz procesów normalizacyjnych i sposobów ich powstawania. Niemniej jednak możliwe jest wykorzystanie tego pomysłu na różne sposoby: zarówno w kontekście szerszych badań, prowadzonych systematycznie na różnych grupach społecznych z uwagi na konkretne metody komunikowania się i generowania relacji między pojęciami, koncepcjami czy stanowiskami, jak i w roli narzędzia projektowego, służącego 
inicjowaniu debat (o transformation design) i wprowadzeniu pojęć związanych z zagadnieniem projektowania transformacji w komunikacje.

Kompleksowość zagadnień z obszaru transformation design widziana bywa przede wszystkim jako problem utrudniający czy wręcz uniemożliwiający poruszanie tego tematu w komunikacji. Przedstawione tu badanie eksploracyjne wydaje się o tyle ciekawe, że wykorzystuje ową kompleksowość jako aspekt pozytywny:

- poznawczo, jako szansę na śledzenie procesów komunikacyjnych i normalizacyjnych zachodzących przy wprowadzaniu tak złożonego i „nienormalnego” tematu do debat społecznych,

- w relacji do procesów informacyjnych, aby lepiej dostrzec i zrozumieć, jakie powiązania między wieloma elementami są logiczne i zrozumiałe z intuicyjnego punktu widzenia uczestników komunikacji,

— strategicznie, aby rozpropagować informacje o transformation design, a tym samym negocjować rolę i znaczenie tego obszaru wiedzy oraz udostępniać go szerszej grupie odbiorców, nie tylko w kontekstach naukowych czy dydaktycznych.

\section{Bibliografia}

Bodin Ö., Tengö M., Disentangling intangible social - ecological systems, „Global Environmental Change" 22, 2021, nr 2, s. 430-439, doi:10.1016/j.gloenvcha.2012.01.005.

Burns C., Cottam H., Vanstone C., Winhall J. / Design Council, Transformation Design. RED Paper 02, London 2006, http://www.designcouncil.org.uk/resources/report/red-paper-02-transformation-design.

Chappin E.J.L., Ligtvoet A., Transition and transformation: A bibliometric analysis of two scientific networks researching socio-technical change, „Renewable and Sustainable Energy Reviews” 30, 2014 s. 715-723, doi:10.1016/j.rser.2013.11.013.

Ciążela A., Postrzeganie osób dbających o środowisko przez młodych Polaków, „Studia Ecologiae et Bioethicae" 13, 2015, nr 4, s. 65-84, doi:10.21697/seb.2015.13.4.03.

Entman R.M. Framing: Towards clarification of a Fractured Paradigm, [w:] McQuail's Reader in Mass Communication Theory, red. D. McQuail, London 2002, s. 390-397.

Fleischer M., Konstrukcja rzeczywistości 3, Kraków 2017.

Fleischer M., Niekomunikowalność, [w:] Język i tekst w ujęciu strukturalnym i funkcjonalnym, red. A. Dudziak et al., Olsztyn 2017, s. 67-83.

Fleischer M., Ogólna teoria komunikacji, Wrocław 2007.

Fleischer M., Siemes A., Świadomość i przynależność subkulturowa wśród mtodzieży, [w:] Badanie komunikacji / Projektowanie komunikacji, t. 3, red. M. Grech et al., Kraków 2020.

Fleischer M., Siemes A., Grech M., Stabilność polskiej i niemieckiej symboliki kolektywnej, Wrocław-Kraków 2021.

Irwin T., Transition Design: A Proposal for a New Area of Design Practice, Study, and Research, „Design and Culture” 7, 2015, nr 2, s. 229-246, doi: 10.1080/17547075.2015.1051829.

Irwin T., Kossoff G., Tonkinwise C., Scupelli P., Transition Design 2015, https://design.cmu.edu/ sites/default/files/Transition_Design_Monograph_final.pdf.

Link J., Normalismus. Konturen eines Konzepts. „kultuRRevolution Zeitschschrift für angewandte Diskurstheorie" 1992, nr 27.

Link J., Normale Krisen? Normalismus und die Krise der Gegenwart, Konstanz 2013. 
Link J., Versuch über den Normalismus. Wie Normalität produziert wird, Opladen 1998.

'Normalität' im Diskursnetz soziologischer Begriffe, red. J. Link, T. Loer, H. Neuendorff, Heidelberg 2003

Ontario Biodiversity Council, Communicating Biodiversity \& Climate Change. A Guide for Crafting Effective Messaging, Ontario 2017, http://ontariobiodiversitycouncil.ca/wp-content/uploads/Biodiversity-and-ClimateChange-August2017.pdf.

Popkiewicz M., Kardaś A., Malinowski S., Nauka o klimacie. Mechanizmy działania systemu klimatycznego. Zmiany klimatu w przeszłości i obecnie, Warszawa 2019.

Radykalny konstruktywizm. Antologia, red. B. Balicki, D. Lewiński, B. Ryż, E. Szczerbuk, Wrocław 2010.

Sangiorgi D., Transformative Services and Transformation Design, „International Journal of Design" 5, 2011, nr 2, http://www.ijdesign.org/index.php/IJDesign/article/view/940/344.

Siemes A., Kryzys jako stan normalny - o normalizacji rzeczy nie do przyjęcia. Zarys projektu badawczego, [w:] Autopromocja, autoprezentacja, wizerunek w komunikowaniu masowym, t. 5. Btad, kryzys, skandal, red. E. Biłas-Pleszak et al., Katowice 2019, s. 113-128.

Siemes A., Kto ma naprawić świat? Badanie na temat globalnego ocieplenia oraz szczytu klimatycznego COP24 w Katowicach, [w:] Badanie komunikacji / Projektowanie komunikacji, t. 3, red. M. Grech et al., Wrocław-Kraków 2020, s. 117-149.

Siemes A., Normalność z perspektywy obserwatora — diagnoza, Łódź 2015.

Siemes A., Transformation design w kontekśsie projektowania komunikacji i badań normalności, Kraków 2020.

Sommer B., Welzer H. Transformationsdesign. Wege in eine zukunftsfähige Moderne. München 2017.

Rokicka E., Woźniak W., W kierunku zrównoważonego rozwoju. Koncepcje, interpretacje, konteksty. Łódź 2016, http://socjologia.uni.lodz.pl/pliki/32-w_kierunku_zrownowazonego_rozwoju. pdf.

Stockholm Resilience Centre, Cracking the social-ecological code. New model disentangles interdependencies between social and ecological systems, Stockholm 2021, https://www.stockholmresilience.org/research/research-news/2012-03-26-cracking-the-social-ecological-code.html.

Stockholm Resilience Centre, Interacting complexities, Stockholm 2021, https://www.stockholmresilience.org/research/research-themes/interacting-complexities.html.

Transformation Design. Perspectives on a New Design Attitude. red. W. Jonas, S. Zerwas, K. von Anshelm, Basel 2015.

United Nations, Department of Economic and Social Affairs, Sustainable Development, The 17 Goals, https://sdgs.un.org/goals.

Welzer H., Samodzielne myślenie, przeł. V. Grotowicz, Słupsk 2016.

Studenckie Prace Prawnicze, Administratywistyczne i Ekonomiczne 38, 2021

(C) for this edition by CNS 